\title{
NEW REGIONALISM AS A PART OF THE TRANSFORMATION STRATEGY - CASES IN CENTRAL AND EASTERN EUROPE AND ASIA (CZECH REPUBLIC, RUSSIA AND CHINA)
}

\author{
Pavel Hnát, Eva Cihelková*
}

\begin{abstract}
:
New Regionalism differs markedly from previous development of regional integration. These changes are connected mainly to the necessity of regionalism to react to changing global conditions, new world political order and entrance of new actors into regional integration (i.e. states and superpowers that did not take part in previous waves at all or on a limited scale, i.e. China). This applies also for the transforming countries, at which the regionalism can be observed as late as in its third wave during the 1990s (which applies for the Central and Eastern Europe as well as for the Commonwealth of Independent States' countries) or even later (which applies for China). The aim of this paper is to compare the role of the New Regionalism in most eminent cases in the three parts of the transforming region: in Central and Eastern Europe, in the Commonwealth of Independent States' region and in East Asia. As cases, the Czech Republic, Russia and China were selected, which should enable the study of not only regional aspects, but also selected global impacts of regionalism.
\end{abstract}

Keywords: New Regionalism, transformation strategy, Czech Republic, Russia, China

JEL Classification: F02, F13, F15, F55

\section{Introduction}

New Regionalism is, as far as its substance is concerned, defined as an exchange of market access rights within a limited group of partners on a basis of Preferential Trade Agreements (PTAs). Taking a time aspect into account, it is a third wave of regionalism, which stroke the whole World Economy in the 1990s, and differs markedly form previous development of regional integration. The difference is not only in unprecedented increase in the number of PTAs (quantitative changes of regionalism), but also in overall change of the approach to regionalism (qualitative changes) and in existence of new types of regional agreements (formal changes). These changes are connected mainly to the necessity of regionalism to react to changing global conditions, new World Political

* University of Economics, Faculty of International Relations, Prague (hnatp@vse.cz, cihelka@vse.cz). This paper was worked out within a framework of the EU-China European Studies Centres Programme, ESCP/G001-RMU-11, and within the Czech Science Foundation Project No. GAČR 402/07/0253. 
Order and entrance of new actors into regional integration (i.e. states and superpowers that did not take part in previous waves at all or on a limited scale).

Without inspecting the character and features of the New Regionalism closer, let us summarize that as a result of three types of changes of regionalism, existence of new regional integrations or reformulation of the existing ones is a fact; with purpose to be able to react to changing conditions in the World Economy, i.e. namely to the globalization and its economic, political and security challenges. Under the economic challenges, the New Regionalism reacts by liberal approach that leads to the development of free movement of goods, services and production factors, which are today crucial for national and regional competitiveness; to the political and security challenges by emphasizing political cooperation and by selection of PTAs partners. However, the concrete features of the New Regionalism differ in particular regions (according to local specificities and approaches to regionalism), the challenges of globalization are universal and thus they authorize us to search for progressive features of the New Regionalism in all regional integrations in the World Economy today.

As far as transforming countries are concerned, regionalism can be observed as late as in its third wave during the 1990s. Sooner, the development of regionalism was disabled by a bipolar division of the European continent and world. The specificity of the regionalism of the transforming countries of Europe and Asia, however, is not only the time of its creation, which classifies it to the New Regionalism. It lies also in a whole range of its progressive features, which resulted from concourse of regionalism with transformation process, i.e. the complex strategy of transformation towards modern and open economy. Just the efforts to renew and establish as fast as possible the economic links with the rest of globalized World Economy became a milestone for the development of regionalism in these regions.

Even though regionalism has played an important role in the transformation process of all countries in the region, the transformation strategy substantially differs among the countries of the Central and Eastern Europe (CEE) and Asia. Similarly, their approach towards the New Regionalism varies markedly. This paper thus aims at comparison of the role of the New Regionalism in most eminent cases in the three parts of the transforming region: in Central and Eastern Europe, in the Commonwealth of Independent States (CIS) region and in East Asia. As cases, the Czech Republic, Russia and China were selected, which should enable the study of not only regional aspects, but also selected global impacts of regionalism.

\section{Czech Republic: Regionalism as a Tool of the Accession Process}

The Czech Republic's accession to the European Union (EU) in May 2004 is a milestone for the fulfillment of its transformation and regionalism strategy. As a matter of this fact, also its approach to regionalism is (similarly as the one of other CEE countries) directly connected to the EU Eastern Enlargement process; thus it must be examined within its context. This connection results from impressive influence of the $\mathrm{EU}$ on the sub-region of CEE during the pre-accession period as well as from the foreign policy aims of the Czech Republic after the end of bipolarity. Main goal of the Czech Republic as well as of other CEE countries was namely their return into European integration structures; in political, economic as well as cultural sense. 
Basic instrument of EU influence on the CEE countries, which also gave pace to the transformation process during the pre-accession period, were the European Agreements, on the bases of which free trade areas between the EU and particular candidate states were built. All in all, they were the Association Agreements between the EC/EU and its candidate countries which constituted a framework of mutual cooperation in the areas of economic integration as well as legal and social environment (i.e. for meeting the Copenhagen criteria). In mutual relations between the EC/EU and CEE countries, the European Agreements created a situation, where the relations between EC/EU and particular candidate countries were better and more firmly institutionalized than their mutual relations.

The European Agreement between the European Community (EC) and the Czech Republic was signed in 1990 as interim, governing the relations before the division of Czechoslovakia, and subsequently as final, effective since February 1995. On the basis of it, asymmetric trade liberalization for industrial goods was applied, however, also the Czech Republic eliminated its trade barriers sooner than requested. Besides gradual creation of the free trade area for industrial goods and elimination of quantitative restrictions in agriculture, the European Agreement had following main features: implementing the national regime for trade in services; creating conditions for free movement of capital and workers; legal and technical norms' and standards' harmonization; further broad cooperation in economic and political area.

By its institutional provisions, the European Agreement seemingly aimed to create as strong as possible framework of mutual integration, which was, at the example of the Czech Republic, fulfilled by the full EU membership in 2004.

However, already during the pre-accession period, it was possible to examine the effects of the Agreement on economic relations between the Czech Republic and the EU. It did not result exclusively from the existence of the European Agreement; also time (the CMEA and existing economic order collapse) and psychological (efforts on presence in perspective Western markets) factors must be taken into account. However, as a matter of this development, the share of the EU in the trade of the Czech Republic (as well as other CEE countries) increased markedly, amounting to more than $85 \%$ for exports and almost $80 \%$ for imports at the end of pre-accession period. However, this number represents today's EU as a whole (i.e. also other CEE countries that acceded the $\mathrm{EU}$ in 2004), the share of the EU-15 has always been predominant; concrete numbers are displayed in Table 1.

Table 1

Long-term Trends of the Czech Republic's Foreign Trade (in mil. CZK)

\begin{tabular}{|l|c|r|r|r|r|r|}
\hline \multirow{2}{*}{ Country / Grouping } & \multicolumn{2}{|c|}{1996} & \multicolumn{2}{c|}{ 2000 } & \multicolumn{2}{c|}{2005} \\
\cline { 2 - 7 } & Exports & \multicolumn{1}{|c|}{ Imports } & Exports & Imports & Exports & Imports \\
\hline EU-25 & 492129 & 583343 & 955141 & 930640 & 1575994 & 1300542 \\
\hline EU-15 & 352489 & 471068 & 768746 & 770507 & 1239209 & 1057277 \\
\hline developing countries & 30358 & 35389 & 42842 & 57617 & 66781 & 101909 \\
\hline CIS & 29275 & 62132 & 28400 & 97157 & 58785 & 142725 \\
\hline Total & 601680 & 754670 & 1121099 & 1241924 & 1873863 & 1834370 \\
\hline
\end{tabular}

Source: Statistical Yearbook of the Czech Republic 2006, http://www.czso.cz/. 
Table 1 shows the main groups of trading partners of the Czech Republic in the second half of the pre-accession process and in the first year of the Czech Republic's EU membership. Its data support the argument that EU-15 has been the main trading partner of the Czech Republic with markedly growing absolute tendency. In relative numbers, the share of EU-15 in the Czech Republic's exports and imports rose from 58.6\% in 1996 to $66.1 \%$ in 2005 and declined from $62.4 \%$ in 1996 to $57.6 \%$ in 2005 , respectively.

Additionally, the data of Table 1 enable us to conceptualize the positive influence of EU membership on Czech Republic's trade balance. During the pre-accession period, the Czech Republic has had a negative trade balance, i.e. its imports were higher than exports. The accession process and extensive trade liberalization with the EU was seen as a way to improve the trade balance, i.e. to increase the export opportunities and competitiveness on developed markets. Indeed, at the end of the accession process and in the first years of the EU membership, the trade balance of the Czech Republic (and especially as far as the trade with EU-15 is concerned) changed into positive. However, these trends cannot be proven by a long time series analysis, it is generally emphasized that the institutional change caused by the accession process as well as the pressure on the increase in competitiveness of the Czech Republic has had a positive influence on the Czech Republic's external trade and namely on exports. After one year of the EU membership, Czech imports and exports increased by $17.5 \%$ and $23.8 \%$, respectively, which means an improvement of the trade balance by CZK 78.5 billions and a positive trade balance (Czech Statistical Office, 2005, p. 3).

As far as other expected effects of the EU accession are concerned, it is emphasized that the financial stability was not influenced much. In spite of the expected increase in consumer prices, the inflation in the Czech Republic remained under the EU average; and was influenced rather by the tax changes than by the accession itself. Similarly the fiscal balance, the main problem in Czech Republic's efforts of meeting the Maastricht criteria, was influenced rather by domestic factors. As far as the negative effects are concerned, namely the increase in transport and connected threats for the environment are most frequently quoted; they are, however, caused by the increase in economic activity of the Czech firms, which is another positive influence of the EU membership (Czech Statistical Office, 2005, p. 3).

Besides the orientation to the EU itself, which is most important due to the amount of the trade flows, PTAs of the Czech Republic were directed also to other partners of the European region; e.g. free trade areas with the European Free Trade Association (EFTA) countries (i.e. Norway, Iceland, Switzerland and Liechtenstein). Additionally, free trade agreements with Turkey (which has a custom union with the EU) and Israel (which has a free trade area with the EU) had very similar character, too. However, also these agreements are the manifestation of New Regionalism, they must be treated in a broader context, i.e. as a part of the integration into the European Economic Area (EEA) and the European region in broader sense.

As a complement to the Czech Republic's and other CEE countries' orientation to the developed markets in Western Europe, also their mutual regional integration flourished in the pre-accession period. Its crucial aim, besides fostering mutual relations, was the cooperation in the transformation and (EU) association matters. Similarly as the challenges of transformation are both economic and political, two basic types of regional integration became effective in the CEE region: regional fora for 
political and cultural cooperation during transformation (represented e.g. by the Visegrad Group) and economic integration, the aim of which was to liberalize economic relations in the region; the most eminent case among them is the Central European Free Trade Agreement (CEFTA). For the development of the Czech Republic's economic relations with countries of the region during the pre-accession period see Table 2 .

Table 2

Foreign Trade of the Czech Republic with the CEE and CIS, 1993-2003 (in mil. CZK)

\begin{tabular}{|l|r|r|r|r|r|r|r|r|}
\hline Country / Grouping & 1993 & 1995 & 1997 & 1999 & $\mathbf{2 0 0 0}$ & $\mathbf{2 0 0 1}$ & $\mathbf{2 0 0 3}$ \\
\hline \multicolumn{7}{|c|}{ Imports } \\
\hline CEE and CIS Countries & 130614 & 169977 & 197188 & 188364 & 261383 & 275579 & 269303 \\
\hline CEFTA & 86541 & 109452 & 125278 & 127589 & 159071 & 174115 & 177866 \\
\hline Slovakia & 67746 & 78424 & 72514 & 60893 & 74582 & 74569 & 74723 \\
\hline Total & 426084 & 665740 & 859711 & 973169 & 1241924 & 1386319 & 1440733 \\
\hline \multicolumn{7}{|c|}{ Exports } \\
\hline CEE and CIS Countries & 137519 & 160186 & 210937 & 198145 & 236420 & 268922 & 281821 \\
\hline CEFTA & 109848 & 125784 & 159477 & 161653 & 189360 & 215697 & 228932 \\
\hline Slovakia & 83200 & 79480 & 91790 & 75329 & 86056 & 101926 & 109151 \\
\hline Total & 421601 & 566171 & 709261 & 908756 & 1121099 & 1269634 & 1371377 \\
\hline
\end{tabular}

Note: Due to the EU accession, this breakdown was last applied in 2004 Statistical Yearbook.

Source: Statistical Yearbook of the Czech Republic, http://www.czso.cz/.

An important general aspect of the creation and existence of the projects of regional integration in the CEE region is the influence of the European Integration. The EU namely influenced the regional processes in the region contradictorily: on the one hand, it was their important catalyst as it itself pushed for creation of regional cooperation before the EU accession, on the other hand, it however did not come into any form of official relations with the regional integrations formed in the CEE. Additionally, also for the CEE countries the EU accession was more important than their projects of regional cooperation. Namely with respect to the future EU membership, regional cooperation in the CCE region was markedly influenced by the EU as far as its scope, scale and institutional order are concerned.

Nevertheless, the Czech Republic became the leading power of several regional economic integration projects. Firstly, it was the Central European Free Trade Agreement as well as its institutional specificity - the Czech Republic - Slovakia Custom Union, or less important (as far as the amount of trade is concerned) the Free Trade Agreements with Baltic Countries, i.e. Estonia, Lithuania and Latvia. At the example of the Czech Republic, another fact comes to the light, that within the transforming region, these agreements were directed almost exclusively to other euro-oriented countries; relations with Russia, and to it oriented countries, were not granted any special PTAs (probably due to the future EU membership, again). For example, the CEFTA conditions for the accession of third countries directly determined that the candidate for CEFTA membership must have signed an association agreement with the EU; as a matter of this fact CEFTA limited itself seemingly to those countries that searched for strong relations with the EU. 
Since the Czech Republic accession to the EU in May 2004, its external economic relations have been governed exclusively by the EU Common Trade Policy. This fact brought significant changes into Czech Republic's external relations. Without investigating the significant role of the EU in world regionalism further, Table 3 displays most important agreements that govern EU (and thus also Czech Republic) external economic relations today.

Table 3

Typology of the EC Regional Agreements

\begin{tabular}{|l|l|l|}
\hline \multicolumn{1}{|c|}{ Type of trade regime } & \multicolumn{1}{c|}{ Name of agreement } & \multicolumn{1}{c|}{ Countries involved } \\
\hline Single market & European Economic Area (EEA) & Iceland, Liechtenstein, Norway \\
\hline Customs union & & Turkey, Andorra, San Marino \\
\hline Free-trade area & $\begin{array}{l}\text { Chile, Croatia, Faroe Islands, } \\
\text { FYROM, Israel, Jordan, Lebanon, } \\
\text { Malta, Mexico, Morocco, } \\
\text { Palestinian Authority, South } \\
\text { Africa, Switzerland, Tunisia }\end{array}$ \\
\hline $\begin{array}{l}\text { Partnership and cooperation } \\
\text { agreements }\end{array}$ & $\begin{array}{l}\text { Russia and other former } \\
\text { Community of Independent States } \\
\text { countries }\end{array}$ \\
\hline $\begin{array}{l}\text { Non-reciprocal: contractual } \\
\text { preferences }\end{array}$ & $\begin{array}{l}\text { Cotonou Agreements, } \\
\text { Mediterranean Agreements }\end{array}$ & $\begin{array}{l}\text { African, Caribbean and Pacific } \\
\text { countries, Algeria, Egypt, Syria }\end{array}$ \\
\hline $\begin{array}{l}\text { Non-reciprocal: autonomous } \\
\text { preferences }\end{array}$ & $\begin{array}{l}\text { Other developing countries and } \\
\text { members of the Commonwealth of } \\
\text { (GSP), and Stabilization } \\
\text { and Association Agreements }\end{array}$ & $\begin{array}{l}\text { Albania, Bosnia and Herzegovina, } \\
\text { and Serbia and Montenegro } \\
\text { (including Kosovo) }\end{array}$ \\
\hline Purely MFN treatment & $\begin{array}{l}\text { Australia; Canada; Chinese Taipei; } \\
\text { Hong Kong, China; Japan; } \\
\text { Republic of Korea; New Zealand; } \\
\text { Singapore; and USA. }\end{array}$ \\
\hline
\end{tabular}

Source: WTO: Trade Policy Review. EC 2004. Based on Lamy, P. (2002), Stepping Stones or Stumbling Blocks? The EC's approach towards the problem of multilateralism and regionalism in trade policy. The World Economy, November 2002, vol. 25, No. 10, pp. 1399-1413(15). Updated by the authors.

Probably the most impressive are the accession's effects on regional economic integration in CEE. As far as e.g. CEFTA is concerned, all new members of the EU (all 4 original members and Slovenia) had to leave CEFTA in 2004; Bulgaria and Romania by 2007. Even though its future is not especially favourable (remaining EU candidate countries - Croatia and Macedonia - will have to leave CEFTA as well when the accession process is concluded), its significance remains even today in its contribution to economic cooperation between particular candidate states in their pre-accession period, which can be utilized after their EU accession, too.

Today, the Czech Republic is a member of the deepest regional integration in the world and as a middle-sized (or rather small) country it can try to influence the EU future and its ability to adapt itself on global challenges (i.e. to apply progressive features of the New Regionalism and conduct necessary structural reform in European scale). Its 
external relations belong to the exclusive competencies of the EU institutions, today, and Czech Republic external policy provisions thus apply all features of EU External Economic Relations. The experience with the New Regionalism, which was governed by the accession process, contributed widely to the success of the transformation process, too. It reflected itself in the conduction of systemic, institutional as well as structural changes within the transformation process.

Within the systemic changes, namely in liberalization of external economic relations and by restitution of price and exchange rate mechanism, regionalism enabled practical establishing of trade and capital links with the EU (especially through the European Agreements) as well as with other countries. Additionally, it enabled a transformation of existing relations between transforming countries, which could not be abandoned all together (through regional integration in Central and Eastern Europe as well as in Eastern Europe and Central Asia).

Regionalism can also be seen as a part of institutional changes, i.e. changes connected to the formulation and enforceability of legal and institutional framework of social and economic processes, as the PTAs often created the needed framework of an external part of transformation. At the beginning, especially the European Agreements again, together with their strong institutional provisions, applied proven rules of the (Western) world to the CEE countries' foreign trade. Subsequently, the regional integration in the CEE region itself formed autonomous institutional framework for trade, too.

For the future development, however, the connections between regionalism and structural changes within the transformation process (i.e. transforming the inappropriate economic structure into modern and competitive one; both within the market and in its external relations) might be the most important. Regional agreements gave pace to the export orientation of the economies, which due to a large openness of most transforming countries influenced the structure of economies as a whole. They also contributed to countries' stabilization, which was a prerequisite for attracting foreign investments, needed for the transformation success. Structural changes and reforms are even today (both in transforming and developed countries) necessary part of economic strategy, the aim of which is to preserve own competitiveness in global environment.

\section{Russia: Regionalism as a Tool of Preserving Regional Hegemony}

The crucial motive of the Russian New Regionalism has been (immediately after the collapse of the Soviet Union) given namely by the regional position of Russia and its regional hegemony; Russia represents almost $77 \%$ of economic capacity, almost $70 \%$ of exports and almost a half of Foreign Direct Investment (FDI) inflows of the CIS region; (UNCTAD, 2004). Economic position of Russia is additionally markedly increased by its military and strategic position and by its natural resources (especially energetic ones, the import of which represents, e.g. in the trade with EU, 57\% of total EU imports; see Commission, 2003). As a regional hegemon, the Russia became the leader of integration efforts in the region, which means that the regional strategies of other countries have been oriented with respect to its position. Moreover, by its efforts on 
preservation of economic links in the region, Russia has followed also its political ambitions in former USSR territory.

Most important instrument of maintaining economic relations in the region, which were markedly affected by the collapse of the Soviet Union, soon became the Commonwealth of Independent States. It was established in 1991 and however 12 post-Soviet republics became its members, it could not eliminate a drastic decrease in mutual trade. According to Michalopoulos and Tarr (2004, p. 34) by 1996, mutual trade decreased by more than $50 \%$. Data of Table 4 on the one hand signalize absolute increase of trade within the CIS (intra-trade; exports) between 1995 and 2005, however, on the other hand also a relative decrease from almost $30 \%$ to $17,98 \%$, which proves faster growth of external trade (i.e. outside the CIS) in this period. Moreover, the CIS activities were often limited by political disputes and fears of too strong influence of Russia.

Table 4

Intra-trade and External Trade of the CIS, 1995-2005 (in mil. USD and \% of total trade)

\begin{tabular}{|l|c|c|c|c|c|c|}
\hline \multirow{2}{*}{ Trade Flow } & \multicolumn{2}{|c|}{1995} & \multicolumn{2}{c|}{$\mathbf{2 0 0 0}$} & \multicolumn{2}{c|}{2005} \\
\cline { 2 - 7 } & mil. USD & \% & mil. USD & \% & mil. USD & \% \\
\hline Intra-trade & 32882.14 & 29.83 & 28753.36 & 20.03 & 43437.59 & 17.98 \\
\hline External Trade & 77345.98 & 70.17 & 114828.70 & 79.97 & 203755.01 & 82.02 \\
\hline
\end{tabular}

Source: UNCTAD Handbook of Statistics, http://stats.unctad.org/handbook.

Especially the political factors and limited scale of the markets in particular countries, decreased markedly the possible effects from building the free trade area within the CIS and led to a fact that, however, the CIS had partial successes in the situation of massive trade re-orientation, it could not preserve the economic relations existing so far. Additionally, however there is an agreement on custom union (tariffs are namely based on the Russian ones), it is not implemented practically (Michalopoulos nad Tarr, 2004, p. 4). Moreover, the decrease in intra-trade within the CIS, which was seen in spite of relatively marked increase in total trade between 2000 and 2005, is common for most CIS countries; the CIS intra-trade share becomes stabilizing under the $20 \%$ value.

Namely as a result of political and historical reasons, as well as of the geographical proximity to the EU, the Baltic countries did not take part in the CIS project at all. Political factors led to further differentiation of the CIS group, too, which resulted in gradual deepening of integration among selected members. However in 1993, there was an agreement signed on the basis of the CIS, which should deepen mutual integration to the level of economic union (free movement of goods, services, workers as well as of capital; coordination of economic policies; common external trade policy and tariffs); already in 1994, deeper integration was limited to a group of four countries (i.e. Russia, Belarus, Kazakhstan and Kyrgyzstan) as they created a custom union. Subsequently, also Tajikistan was accepted as its full member in 1999; when a full-fledged regional integration, the Eurasian Economic Community (EAEC), was formed on the basis of this custom union in 2000, it had five members. However, its intra-trade is tariff-free today, even in the case of EAEC we cannot speak about absolute application of common 
external tariffs (Michalopoulos and Tarr, 2004, p. 19). In 2006, Uzbekistan became a member of EAEC; Armenia, Moldova and Ukraine enjoy the observer statute, today.

Although Russia intensively seeks the other platforms for deepening economic integration in the region, their success and difficult implementation often depend on political factors and current willingness of partner governments to join these projects (including harmonization of legislature and economic policies). Even though the deep integration projects react on necessity to foster regional competitiveness in global conditions, in many countries (recently namely in Ukraine), they induce fears of power ambitions of Russia. As opposed to the Russia - the Belarus Economic Union, which has enjoyed stable political support since its establishment in 1995, the project of Single Economic Space (SES) launched in 2003 between Russia, Belarus, Kazakhstan and Ukraine is more sensitive to recent development of political situation, namely in Ukraine.

A complement to the multilateral strategies in the region is created by a whole range of bilateral agreements on mutual economic cooperation both between Russia and its partners (deep agreement with Belarus was already mentioned, however, also agreements with Armenia, Georgia and Kyrgyzstan are operational), and between the CIS countries mutually. These agreements supplement the efforts on economic cooperation in the CIS region.

Also for Russia, regionalism is not only a way of fostering regional relations. Additionally, we can trace trans-regional relation, the aims of which are broader efforts on binding contacts with global economy. In this respect, the motives of Russian regionalism are quite similar to the general motives of the New Regionalism elsewhere.

As far as the strategy of Russian trans-regionalism is concerned, the main factor is the structure of Russian exports, which is oriented especially to the export of resources after the overall collapse of traditional economies; similar applies to the rest of the CIS region. Energetic dependence of Europe as well as China's and other states' interests on Russian energetic supplies further increases Russia's importance as a strategic partner. From the above-mentioned there arises a fact that Russia enjoys special relations, which are governed by transregional agreements, especially with the EU and Asian partners.

Since 1997 the relations between Russia and the European Union have been governed by the Partnership and Cooperation Agreement, which belongs relatively high in the system of external economic relations of the EU namely because of its strategic significance: According to the data of the European Commission, in 2005, the mineral fuels amounted to $64.4 \%$ of Russia's imports to the EU, while Russia had a $27.5 \%$ share in imports of these commodities into the EU. From economical point of view, this agreement grants Russia the most favoured nation treatment as it was the WTO member and contains provisions for harmonization of legislature, national treatment in services, intellectual property rights protection and surveillance mechanism. From the current speeches of the EU Trade Commissioner Peter Mendelson $(2005$, p. 4) it is apparent that a future of mutual relations is a complex free trade agreement (i.e. including also free movement of services and capital). Necessity for such an arrangement on mutual relations, however, still is Russia's membership in the WTO, which will be examined further.

Besides the EU-Russia ties, several other trans-regional integrations are worth mentioning within Russia's strategy, namely because of their future potential or scale: 
Black Sea Economic Cooperation (BSEC) was established in 1992 as a regional forum and transformed itself into an international organization in 1999. Today, it has 12 members: Albania, Armenia, Azerbaijan, Bulgaria, Georgia, Greece, Moldova, Romania, Russia, Turkey, Ukraine, and Serbia and Monte Negro. Besides the efforts on cooperation and stability in significant region (namely for the energy resources transit), the BSEC has its economic agenda, too, which aims to the support of transformation processes and eliminate mutual trade barrier. Although this cooperation is quite similar to the CIS, in Russia's regional strategy, it transcends the CIS borders and is directed also to the EU-oriented countries. Even though its economic potential is marked, its economic programme is in its initial stages and, from a regionalism point of view, its importance lies rather in the support of mutual cooperation at the level of intergovernmental forum.

As Russia tries further diversification of its trans-regional strategy, since 1998, it has been also a member of Asia Pacific Economic Cooperation (APEC), which is a regional forum aiming to create a free trade area by 2010 or 2020 based on open regionalism principles and consistency with multilateral liberalization. Moreover, Russia's membership in APEC must be conducted in the context of its reintegration into global economy as well as within its efforts on linking close economic relations with a perspective Asia Pacific region. Current priorities of the Russian Federation for the following period of its membership fully comply with these goals: support of new technologies, energy and APEC members' support for Russia's accession process to the WTO.

APEC's features and principles of its open regionalism and its consequences for multilateralism will be examined further, as they belong principally also to the strategy of China's New Regionalism.

Currently, the process of Russia's accession to the WTO has marked implications for its regional strategy and for the future of Russia's regional agreements both within the CIS region and trans-regionally. As opposed to the Czech Republic (or formerly Czechoslovakia), the Russian Federation (and the Soviet Union) had not sustained its GATT membership. As a matter of which, Russia or other CIS countries were not the GATT members at the end of the Cold War. Meanwhile some of the post-Soviet republics applied for the GATT membership and some of them even acceded GATT/WTO after the year 2000 (Kyrgyzstan in 1998, Georgia in 2000 and Moldova in 2001), the accession process of Russia and other CIS countries has not finalized yet, as displayed in Table 5.

Russia applied for WTO (respectively GATT) membership in 1993 with an aim to support the ongoing market oriented reforms. Even before it had acceded other principal global economic organizations - the International Monetary Fund (IMF) and International Bank for Reconstruction and Development (IBRD). The main motives of Russia's efforts on WTO accession, which are closely connected to the strategy of Russian New Regionalism, can be, according to Ko (2005), summed up as follows: to improve the conditions for Russian production exports; to abolish discriminative measures for Russian exporters; to gain access to the international dispute solution mechanism; to create a better conditions for the FDI inflow by implementing the WTO standards; and to increase the export opportunities for Russian goods in WTO countries. 
Table 5

CIS Countries Accession to the WTO Process

\begin{tabular}{|l|l|l|l|}
\hline \multicolumn{1}{|c|}{ Country } & \multicolumn{1}{|c|}{ Application date } & \multicolumn{1}{|c|}{$\begin{array}{c}\text { Working Group } \\
\text { establishment }\end{array}$} & \multicolumn{1}{c|}{$\begin{array}{c}\text { Final Report } \\
\text { Proposal }\end{array}$} \\
\hline Azerbaijan & June 1997 & July 1997 & - \\
\hline Belarus & September 1993 & October 1993 & April 2005 \\
\hline Kazakhstan & January 1996 & February 1996 & May 2005 \\
\hline Russian Federation & June 1993 & June 1993 & October 2004 \\
\hline Tajikistan & May 2001 & July 2001 & April 2005 \\
\hline Ukraine & November 1993 & December 1993 & August 2005 \\
\hline Uzbekistan & December 1994 & December 1994 & - \\
\hline
\end{tabular}

Note: Other three CIS Countries (i.e. Georgia, Kyrgyzstan and Moldova) have already been WTO members. Armenia and Turkmenistan have not applied for the WTO membership yet. Source: WTO, http://www.wto.org/english/thewto_e/acc_e/status_e.htm.

Russia application for membership was followed by a creation of a Working Group which examined Russia's fulfillment of the membership criteria till 1994, however, it did not adopted its Final Report until October 2005. By this act, the Russia's accession process entered its final stage. The main problems which have accompanied the accession process are following: product market liberalization (which has induced extensive protests of some strategic branches of Russian economy and made larger progress as late as after 2001), two systems of prices in Russian energy sector (caused by a domestic energy markets regulation), agricultural subsidies, services liberalization, and legislative harmonization with international law and GATT provisions (Ko, pp. 5-9).

Russia's major trade partner - the European Union has already supported Russia's accession to the WTO, however as late as in July 2006 the United States were the main opposition to the process (officially because of agricultural export barriers); even though at the previous bilateral presidential meeting in Bratislava, the USA had accepted a soon accession of Russia into the WTO. Another opponent was Georgia, which took its signature on the final protocol back because of mutual trade disputes. In late 2006, namely these circumstances seemed to delay Russia's accession for some other time. No matter the time of Russia's final accession to the WTO (many terms have been stated in this respect and postponed regularly), Russia's WTO membership will have a marked impact both on Russia's economy and on the system of its regional agreements and overall regionalism strategy.

Besides the achievement of above mentioned goals, the main positive impact of the WTO accession on the Russian economy is expected in an increase of FDI inflow induced by services sector liberalization and capital flows liberalization, an increase in trade flows caused by external relations' liberalization, increased labour productivity caused by technology transfer and investment and in an improved position of Russian producers in antidumping disputes. A mid-term slowdown is, on the other hand, expected in those branches that have been protected strongly so far (e.g. automotive sector); as Rutherford and Tarr (2005) suggest. Institutionally, the WTO accession means a strengthening of liberalization tendencies and structural reforms and a 
full-fledged position in global economy. Within a context of globalization and New Regionalism, both these aspects are seen as a condition of regional competitiveness.

For the current strategy of Russian regionalism, the WTO accession will mean a stricter regime for regional agreements. However both CIS and EAEC have already been notified to GATT according to GATT Article XXIV, after their members' accession to the WTO greater pressure on consistency of the free trade area and custom union provisions with the provisions of Article XXIV can be expected. According to the revised exceptions from GATT and GATS for the creation of a regional integration among WTO members (i.e. GATT Article XXIV, GATS Article V and the Enabling Clause), ${ }^{7}$ the regional agreement has to fulfill three main conditions. Firstly, the protection against non-members must not exceed the level existing before the agreement was concluded. Secondly, the tariffs within the integration must be decreased to zero and also other discriminatory measures in mutual trade must be eliminated. Additionally, this all should be done within 10 or less years schedule. And thirdly, the agreement has to cover substantially all trade.

During the analysis of Russia's regional agreements in previous parts, it was usually concluded that these agreements do not meet all their goals and often are influenced by political factors in mutual relations. Additionally, some WTO inconsistent rules can still be found within their mechanisms. After Russia's accession to the WTO, these agreements would probably have to be reconsidered strictly and their consistency with WTO rules should be examined. A positive influence of this fact could especially lie in clarifying priorities of Russia's regional strategy and a stronger support for the most competitive projects of regional integration in the region. Namely the comprehensiveness and flexibility of regional agreements' system is usually seen as a precondition of a positive interaction between regionalisms and multilateralism with clear positive influence on Russian economy.

Subsequently, another increase in the number of agreements with other partners in which Russia will be involved can be expected after its accession to the WTO. Entirely within the global strategy of the New Regionalism, a complex (i.e. liberalizing not only trade in goods but also in services, capital movement and labour standards) agreement with the EU and other major partners can be concluded. With respect to current wave of Asia-Pacific bilateralism, also bilateral agreements between Russia and Japan, Korea or China can be foreseen, which would definitely induce a reaction of other global players including the United States.

Moreover, the whole process of regional consolidation would be accelerated further by other CIS countries' accession to the WTO (see Table 7). Together with a current tendency on increasing the WTO's rules on regional integrations' supervision, the mutual consistency and transparency of the agreements in the region would be mostly important leading to a more competitive position in the whole CIS region. The New Regionalism is thus seen as a way to consolidate the region inside and to foster its global position and competitiveness abroad.

\section{China: Regionalism as a Tool of Addressing Global Aspirations}

Before inspecting the role of the New Regionalism in China's transformation strategy, it is important to suggest that especially as far as its economic substance is concerned, 
despite political and institutional differences, the transformation process of China can be in many aspects compared with the processes that the CEE countries have gone through during the 1990s. Main differences arise form the fact, that unlike most other transforming countries, China's transition from centrally planned economy towards the market economy has other institutional aspects, which are based on gradual and selective transformation. Particularly in this respect, China's transformation strategy differs from the one that especially the Czech Republic went through (i.e. a rapid and overall change of the economical as well as political system). Other differences arise from China's level of economic development; being a developing country, the transition mechanism differs further from those implemented especially in the most developed CEE countries. On the other hand, basic parts of the transformation process are given namely by the demands of globalized world and in this respect are common for all transforming countries; however, their strategies or economic development at the beginning of the transformation process can be different.

Similarly as in other transforming countries, the transformation process in China consists of systemic, institutional and structural changes; the difference thus mainly arises when the scale and pace of the changes are concerned. Key elements in China's transition process have been the reduction of the role of state-owned enterprises; gradual and selective introduction of market incentives; regulatory reforms of price system, market mobility regime, external trade and FDI. ${ }^{9}$ Within the systemic changes, especially the latter two aspects, i.e. external trade and FDI regimes, must be emphasized as they are most closely connected with the globalization challenges. In this respect, the New Regionalism is an important part of China's transition as well, however it has developed even later than in other transforming countries.

The more important is the fact that within the transforming countries of East Asia, China has very soon become a crucial player of the New Regionalisms, which influences its development globally. Meanwhile also for China, the New Regionalism creates an important part of the transformation strategy, i.e. the tool for a rapid and strong integration into global economy, its global impacts differ substantially. Taking into account the speed of China's economic development, its regional and strategic position and competitive potential, China's integration into the world economy changes the world economy and an overall strategy of regionalism much. As a matter of this fact, integration into global trading and economic system as the main objective of China's regionalism strategy is much broader than a part of transformation strategy, to which it, however, is strongly connected.

According to Sun (2005, pp. 45-46), China's integration into global economy began with its open door policy in the late 1970s and early 1980s; since than, China has step by step approached its target of a socialist market economy. Even then, China, however, did not implement any marked strategy of its New Regionalism and stood aside most mushrooming projects of regional integration in the region. However in 1991, China acceded Asia Pacific Economic Cooperation - an eminent result of the New Regionalism in Pacific area, its position towards regional integration changed even later. The principal tool of its accession into the world economy thus remained namely in its accession process to the WTO.

China's WTO accession process was successfully fulfilled on $11^{\text {th }}$ December 2001, when China legally became a member of the World Trade Organization. The accession 
agreement called namely for extent liberalization in manufacturing trade, abolishing extent subsidies to state-owned firms, reduction of subsidies in agriculture, and liberalization of services sector as Whalley (2005, pp. 1-3) suggests. With the schedule by 2007 , these steps represent a substance of a marked structural and policy change of the Chinese economy and can thus be explained as a gear of the transformation process, similar to the effects of European Agreements on the CEE countries and the Czech Republic, examined above. Besides the general effects of the WTO accession, i.e. MFN treatment by the WTO members, access to the dispute settlement mechanism, China sought for a structural change in its FDI inflow and for the support of domestic structural and policy reforms that should ensure economic growth. Table 6 displays main indicators of the FDI inflow into China in comparison with other developing countries, indicating an increasing share of China on the overall FDI inflows.

Table 6

Foreign Direct Investment in China and Other Developing Countries (in mil. USD)

\begin{tabular}{|l|c|c|c|c|c|c|}
\hline \multirow{2}{*}{$\begin{array}{c}\text { Country / Group of } \\
\text { Countries }\end{array}$} & \multicolumn{2}{|c|}{$\mathbf{1 9 9 0}$} & \multicolumn{2}{c|}{$\mathbf{2 0 0 0}$} & \multicolumn{2}{c|}{2005} \\
\cline { 2 - 7 } & $\begin{array}{c}\text { FDI } \\
\text { inflows }\end{array}$ & $\begin{array}{c}\text { FDI inward } \\
\text { stock }\end{array}$ & $\begin{array}{c}\text { FDI } \\
\text { inflows }\end{array}$ & $\begin{array}{c}\text { FDI inward } \\
\text { stock }\end{array}$ & $\begin{array}{c}\text { FDI } \\
\text { inflows }\end{array}$ & $\begin{array}{c}\text { FDI inward } \\
\text { stock }\end{array}$ \\
\hline China & 3487 & 20691 & 40715 & 193348 & 72406 & 317873 \\
\hline $\begin{array}{l}\text { Developing Countries } \\
\text { excluding China }\end{array}$ & 32394 & 343366 & 212464 & 1546378 & 248231 & 2336160 \\
\hline
\end{tabular}

Source: UNCTAD Handbook of Statistics, http://stats.unctad.org/handbook.

Taking into account the main challenges for China's sustained growth by UNCTAD (2005, pp. 38-39), i.e. the need of a structural changes towards the most competitive manufacturing branches and namely services; ever faster need of innovations and modern technologies transfer; more equal distribution of economic growth benefits; and (in a broader sense) the need of fostering domestic consumption, increase of the know-how bringing investment and a structural change in the FDI inflows is mostly desired for the sustainability of China's rapid economic growth.

According to the recent UNCTAD reports, e.g. Dullien (2005, pp. 141-151), the WTO accession namely provided the foreign companies with a greater access to the service sector including the most developed ones such as financial services, telecommunications, or legal services. Together with difficult international tradability, this fact attracts sophisticated FDI inflow with another structure into the Chinese economy and changes the character of FDI from "efficiency-seeking to the market-seeking (i.e. oriented to domestic demand) ones", Dullien (2005, pp. 144). In the service sector, both changes can probably have important positive influences as sophisticated services support domestic production by an increased efficiency as well.

On the other hand Dullien (2005, p. 144) further suggests that increase of on the domestic demand oriented FDI inflows in the manufacturing industry, caused by external liberalization according to the WTO schedule and increased possibilities for re-export, can have more marked negative effects (e.g. domestic investment crowding-out and balance of payment imbalance caused by future repatriation of incomes). Similarly as in other transforming countries including the recent experience of the Czech Republic with FDI inflows, there are significant positive effects of the FDI 
inflows and significant risks. Provided that these risks however induce a needed policy changes as well, they can accelerate the positive structural reforms and policy changes of the domestic economy.

The main long-term positive influence of the WTO accession thus lies in the institutional part of the transformation process, i.e. in the improvement of institutional framework of domestic policies that are caused by the WTO commitments themselves as well as by the integration into the global economy, which induces greater competition and consequent policy and structural changes. Here the situation is quite similar to the case of the Czech Republic with the only difference that for the Czech Republic, the crucial part of institutional change was caused by the European Agreements and that domestic policy makers themselves introduced these changes more rapidly, which was connected namely by a profound change of the political system.

As was already presented on the case of Russia, the WTO accession brings additionally large effects on the system of regional trade agreements. This applies also for China, even though it started to use the New Regionalism as a tool of its external relations liberalization later. As the New Regionalism offers an extent tool of trade liberalization as well as services and capital liberalization, it is closely connected to all the aspects of China's WTO accession that were mentioned above.

China's New Regionalism occurred as late as after 2000 and is thus directly influenced by the newly acquired WTO membership. Initially, it has been directed mainly into the South-East Asia region, which is quite understandable due to the extensive orientation of trade to this region. According to the data of Table 7, the share of exports to Asian (especially South-East Asian) developing or emerging partners traditionally represent a third of Chinese exports; imports form these countries have increased extensively to $43 \%$ share as well. Additionally, in 2005 the main partners from this region were Hong Kong, Korea, Singapore, Malaysia and Thailand. Taking into account the share of developed countries from the broader Pacific Region (i.e. United States, Japan and Australia), the regional pattern of China's New Regionalism is clear.

With respect to the trade structure and future potential, it is not surprising that the initial steps of China's New Regionalism led to the Pacific and East-Asian region and the regionalism strategy thus does not differ from those implemented by the Czech Republic and Russia, i.e. all countries stressed the relation with its regional partners at first. As was already mentioned above, China acceded the APEC in 1991; this step was probably closely connected with the future WTO accession as the APEC represents an eminent case of open regionalism, the aim of which is a broad liberalization with respect to the multilateral rules that should foster the regional and global trading system. Addressing namely the competitive potential of the Pacific region, the APEC connects China with the NAFTA countries, selective Latin American countries, most East-Asian countries including most ASEAN members, Australia and New Zealand, and with Russia. As well as for other countries of the region, the APEC represents a broad basis of potential partners of other (more narrow or even bilateral) trade agreements. Should the APEC's positive influence on regional and global economic system prevail, these agreements however must be mutually consistent and similar in scope to avoid the negative effects of the "spaghetti bowl". 
Table 7

Structure of China's Foreign Trade (in mil. USD and \%)

\begin{tabular}{|c|c|c|c|c|c|c|}
\hline \multirow{2}{*}{ Trading partners } & \multicolumn{2}{c|}{1980} & \multicolumn{2}{c|}{ 2000 } & \multicolumn{2}{c|}{2005} \\
\cline { 2 - 7 } & mil. USD & \% & mil. USD & $\%$ & mil. USD & \% \\
\hline \multicolumn{7}{|c|}{ Exports } \\
\hline Developed economies & 8603 & 48 & 143587 & 58 & 420806 & 55 \\
\hline EU-25 & 3003 & 17 & 40783 & 16 & 143851 & 19 \\
\hline USA and Canada & 1120 & 6 & 55320 & 22 & 175130 & 23 \\
\hline Asia & 4032 & 22 & 42373 & 17 & 86052 & 11 \\
\hline Developing economies & 7837 & 43 & 101978 & 41 & 317115 & 42 \\
\hline Asia & 6665 & 37 & 89778 & 36 & 275090 & 36 \\
\hline \multicolumn{7}{|c|}{ Imports } \\
\hline Developed economies & 15035 & 77 & 103373 & 46 & 254201 & 39 \\
\hline EU-25 & 3737 & 19 & 30130 & 13 & 73559 & 11 \\
\hline USA and Canada & 4647 & 24 & 25230 & 11 & 56540 & 9 \\
\hline Asia & 5169 & 27 & 41856 & 19 & 101542 & 15 \\
\hline Developing economies & 3172 & 16 & 107785 & 48 & 329565 & 50 \\
\hline Asia & 2023 & 10 & 92315 & 41 & 281516 & 43 \\
\hline
\end{tabular}

Source: UNCTAD Handbook of Statistics, http://stats.unctad.org/handbook.

In 2001, China acceded the Bangkok Agreement, today's Asia-Pacific Trade Agreement (APTA). However the agreement was signed already in 1975 at the United Nations Economic Committee for Asia and Pacific (ESCAP), its main achievements in trade liberalization are influenced by China's accession in 2001. Having connected Bangladesh, India, Laos, Korea, Sri Lanka and China by a preferential agreement, it represents a potential of mutual trade relation in the western part of the region. Although its potential is not as huge as the ESCAP initially planned, its importance arises today also due to India's aspirations on joining the APEC; efforts of other countries (e.g. Mongolia, Nepal or Bhutan) on accession to APTA; and due to the population and economic potential that the APTA covers having both China and India as members.

Subsequently, China moved on with its New Regionalism strategy, being inspired by the extensive rise of Asian Bilateralism, which was caused namely by Japan's late entry into the New Regionalism. In late 1990s Japan introduced its complex Economic Partnership Agreements (EPAs), which were aimed at its East-Asia partners and later to other APEC members (e.g. Mexico). These bilateral agreements induce a great reaction among other APEC countries (e.g. Australia or even the United States) and complicated the APEC's spaghetti bowl further. As they offer broad coverage and complex liberalization of the New Regionalism, they do not threat regional trade system and can even support it. Unlike the Japan's EPAs, China's agreements are not that broad in their scope and clear in the commitments they induce. According to Whalley (2005, p. 11), this especially applies for the Hong Kong and Macao Closer Economic Partnership Agreements that are both somehow vague and leave much for "a process of ongoing trade management" based on current needs and situations. Unfortunately, similar situation applies also for other new agreements or frameworks in the region, as to Whalley (2005, p. 11), which are seen as the first ties to the region's (or even world's) 
most dynamic economy. In this respect, institutional arrangements and diversity in coverage of China's New Regionalism may cause a risk to the comprehensibility and mutual consistency of the APEC's trade system as well as to the global system which is influenced by the APEC region much.

Another project of broad and complex liberalization (including extensive services liberalization and a possibility of investment, agricultural and other cooperation), which has as well been, according to Whalley's comments, based on a vague framework agreement so far, is the ASEAN-China Framework Agreement on Comprehensive Economic Cooperation signed in 2002. However, in the late 1990s it seemed that regional superpowers' cooperation with ASEAN could be based on the ASEAN+3 framework (i.e. ASEAN, Japan, Korea and China), later development showed that the cooperation will rather run on bilateral or biregional (i.e. ASEAN+1) basis. Nevertheless, efforts on close cooperation with the ASEAN countries is common not only for Japan, Korea and China; and expresses an importance of the regional ties in South-East Asia. China's framework with ASEAN outlines the effort on starting complex free trade area with most and less developed ASEAN members by 2010 and 2015, respectively. Provided that the future free trade area is based on firm commitments of complex mutual agreement, its positive potential for the further development of regional integration in this region could be enormous.

As an evidence of the fact that China has started a strategy of modern and complex New Regionalism, which can be (in case that the future agreements will strengthen their commitments-based institutional framework) compared to any other global regionalism superpower, following framework agreements aimed at future possibility of a complex free trade area creation can serve. In 2003 China signed such an agreement with Australia, in 2004 with New Zealand, in 2006 with Chile (all very active actors of the New Regionalism globally). A possibility of such an agreement is currently examined with South Africa or Gulf Cooperation Council (again, all are usual parties of trans-regional agreements globally). Moreover, with respect to the data of Table 7, the prospect of future arrangements with Singapore or even Japan is probably a matter of time or, more importantly, of a political constellation.

Supposing that China's relation with the USA and Canada can remain being governed by the APEC framework for now, the European Union is the only top trade partner that has not been mentioned so far. This situation is, however, not caused only by the geographical difference between both regions; it is often emphasized that the European Union has not paid the right attention to its relations with world's most dynamic region so far. As with other regions, the EU external relations with East-Asia and China are based on a combination of several levels of cooperation ranging from multilateral frameworks to bilateral agreements. The multilateral project governing the ties between EU and Asia has since 1996 been the trans-regional forum Asia Europe Meetings (ASEM), which today connects 41 countries of Europe and Asia, including China. Its scope is, however, very broad and the possibilities of effective economic integration tools have been only inspected so far.

EU's relations with regional powers (i.e. with Japan, China, India and Korea) are further governed by separate institutional framework of bilateral agreements and regular high-level meetings. Additionally, the EU has a separate institutional 
framework for the relation with the ASEAN, which is often seen as a basis for future EU-ASEAN free trade agreement.

Similarly as in case of the United States or Japan that started to form their own regional integrations relatively late but influenced global regionalism in unprecedented extent, China's approach to the New Regionalism may have an impressive global impact. It is caused namely by the scale of Chinese economy, its competitive potential and position in both regional and global trade and economic system. The more important is the way how China's regional integration will work and which institutional framework they will use. However the WTO membership commitments are a tool to ensuring mutual consistency of regional agreements and their complex coverage, they are not strong enough. Especially in the situation, when the demand on closer economic ties and access to Chinese markets is that big, it is the responsibility of Chinese policymakers to ensure that China's regionalism would not harm regional and global economic systems by inconsistent or discriminatory measures without proper institutional framework.

\section{Conclusion}

The Czech Republic's accession to the EU in May 2004 is a milestone for the fulfillment of its transformation regional strategy. For the system of its regional agreements, it represents a marked change. Today, the Czech Republic's external economic relations are fully governed by the EU Common Trade Policy, which (namely due to Czech Republic's trade orientation) offers, in most cases, better institutionalization and treatment than individual (national) trade policy. The main strategic objective of the Czech Republic thus moves towards building as firm as possible and interests-based position within the economic and political system of the EU. Namely in the Lisbon Strategy context, which seeks for the new reactions of the EU to new global conditions, the Czech Republic can utilize its experience with regionalism directly connected to structural reforms that are, today, needed at the European level, too.

Similarly impressive change for Russia will be represented by its accession to the WTO, however, it will only improve Russia's conditions for utilizing all opportunities that the globalization and regionalism offer. Concerning the unfavourable export orientation of Russia, continuing FDI inflow and better access to main partners' markets will be the most important effects of the accession. Efforts on CIS region economic integration, the cumulative potential of which can markedly increase regional competitiveness, will not lose its importance either. On the contrary, in Eastern Europe and Central Asia, we can expect future increase of regional trade agreements between particular partners or groups of partners. So that this increase would not lead towards incomprehensibility of regional trade system (i.e. spaghetti bowl effect), it is necessary that these agreements are mutually consistent and negotiated with respect to broader liberalization projects. For the development of Russian regionalism, the future WTO accession would probably mean some clarifying of priorities and concentration to the most perspective PTAs in the region. Just the comprehensibility, lucidity and consistency of regional trade system is seen as a main advantage of modern New Regionalism; it would surely contribute to Russia's competitiveness in global conditions, too. 
China's integration into the world economy was governed namely by the WTO accession process and its New Regionalism got the right pace after this process was successfully fulfilled. However China's transformation process differs in many aspects from those that the Czech Republic and Russia went or have gone through, its economic substance is the same. The WTO accession provided the most important influence by its institutional aspects and for future it will further influence the institutional provisions of China's regional trade agreements. For the consistency of APEC and global economic system, this influence is especially important. Taking into account China's economic potential, its transition and New Regionalism strategy has a large global aspect and will influence the development of the World Economy markedly. In this respect, China's New Regionalism has been and will be namely a tool for addressing China's global aspirations. Within the transition process it will further contribute to the sustainability of China's economic growth - the main challenge of China's domestic as well as global aspirations.

Comparative analysis of the three eminent cases of mutual relation between the transformation strategy and New Regionalism especially suggests that its importance lies in the institutional aspects of the transition process. The efforts on global economy reintegration, which are governed both by the New Regionalism agreements and global governance institutions accession, have implemented the needed institutional framework for the transformation process.

Unlike the Czech Republic, Russia and China, however, have a prominent position in the global economy and politics that, in some extent, enable them to formulate their own institutional framework of their ties with the rest of globalizing world, which seeks for the links with them much. Should this "own institutional framework" be inconsistent with multilateral rules and New Regionalism pattern, it could however harm the consistency of global economic system as well as threaten the fulfillment of the transformation process objectives. Additionally, demands on transformation strategy as well as on the strategy of New Regionalism are today governed by the process of globalization and by efforts on global competitiveness. All in all, pressure of globalization and policymakers' efforts on successful transition should enforce the strategies consistency. Then there is no doubt that Russia and China will become crucial players of global regionalism and economy.

\section{References}

Broadman, H.G. (2005), "From Disintegration to Reintegration: Europe and Central Asia in International Trade. An Overview." Washington, DC : World Bank, 2005, p. 5. Available form. http://siteresources.worldbank.org/INTECA/Resources/tradereport-overview.pdf.

Dullien, S. (2005), "FDI in China: Trends and Macroeconomic Challenges," in China in a Globalizing World World. New York, Geneva : United Nations.

Cihelková, E. (2004), "Nový regionalismus: teorie a projevy ve světové ekonomice [New Regionalism: Theory and Trends in the World Economy]." Politická ekonomie, (6), pp. 807-822.

Cihelková, E. (2003), Vnější ekonomické vztahy Evropské unie [External Economic Relations of the European Union]." $1^{\text {st }}$ Ed. Praha : C. H. Beck.

Cihelková, E., Hnát, P. (2006), Regional Integration of the New Member States during the Pre-Accession Period and after Eastern Enlargement. Munich : C.A.P. http://www.cap-Imu.de/ publikationen/2006/cihelkova-hnat.php. 
Cihelková, E., Hnát, P. (2005), "Subregionalismus v EU a APEC [Subregionalism within EU and APEC]." Politická ekonomie, (6), pp. 793-809.

Czech Statistical Office. "Statistical Yearbook on-line". http://www.czso.cz/.

Czech Statistical Office. "Expected Development of the Czech Economy after the EU Accession within the Context of Previous Accession Waves' Experiences”. 2005, p. 3. Available at http://www.czso.cz/.

European Commission, http://trade.ec.europa.eu/.

EU - Russia, European Commission, http://ec.europa.eu/trade/issues/bilateral/countries/ russia/erp.htm.

European Commission, http://ec.europa.eu/trade/issues/bilateral/countries/russia/index_en.htm.

European Commission, http://trade-info.cec.eu.int/doclib/html/113440.htm.

Fiala, P., Pitrová, M. (2003), Evropská unie [European Union]. Brno : Centrum pro studium demokracie a kultury.

Hnát, P. (2005), "Regionalismus ve světové ekonomice [Regionalism in the World Economy]," In Kolektiv autorů: Proměny světové ekonomiky - teorie a realita. Praha : VŠE, Nakladatelství Oeconomica.

Interstate Statistical Committee of the CIS, http://www.cisstat.com/.

Ko, J. (2005), "Russia's Accession to the WTO: Current Status and Prospects." IFANS Policy Brief No. 6/2005. http://www.ifans.go.kr/lCSFiles/afieldfile/2005/11/28/PB_2005_06.pdf.

Mendelson, P. (2005), "Europe's Global Trading Challenge and the Future of Free Trade Agreements." Speech/05/551, Brighton, $26^{\text {th }}$ September 2005, p. 4. http://www.europa.eu.int/.

Michalopoulos, C., Tarr, D. (2004), Are Custom Unions Economically Sensible in the CIS. Washington, DC : World Bank.

Rutherford, T., Tarr, D. (2005), Russia's WTO Accession: What Are the Macroeconomic, Sector, Labor Market and Household Effects? World Bank. Available at http://www.worldbank.org/trade /russia-wto.

Sun, Y. (2005), "Globalisation and the Integration of China into the World Economy," in China in a Globalizing World. New York, Geneva : United Nations, 2005.

Statistical Yearbook of the Czech Republic 2006, on-line, http://www.czso.cz/.

UNCTAD (2005), "Current Issues in the World Economy," in Trade and Development Report, 2005. New York and Geneva : United Nations.

UNCTAD: Handbook of Statistics, http://stats.unctad.org/handbook.

UNCTAD: Key Issues in China's Economic Transformation, http://www.unctad.org/.

Whalley, J. (2005), "China in the World Trading System." CIGI Working Paper No. 2/2005. Waterloo, Ontario : The Centre for International Governance Innovation.

WTO (2004), "Trade Policy Review. EC 2004." Geneva : World Trade Organization.

WTO, http://www.wto.org/. 